\title{
Marine Renewable Energy Policy
}

\section{Some US and International Perspectives Compared}

\author{
BY MICHELLE E. PORTMAN
}

ABSTRACT. This article describes the policy framework for siting, permitting, and developing offshore renewable energy facilities in the United States. It also highlights features of regulatory programs in other countries and makes some comparisons.

Initially, the article presents a brief historical background of US regulatory development, and then it provides a synopsis of the more salient features of the federal siting and permitting program, followed by descriptions of policy frameworks in three other countries - the United Kingdom, Germany, and Portugal. It concentrates on federal policies as set apart from state and local-level policies, on policies encouraging or authorizing construction of offshore facilities, and on those offshore energy technologies considered relevant in the short term by the Alternative Energy and Alternative Use Program of the US Minerals Management Service. These hydrokinetic energy sources are generated in or over submerged lands and include offshore wind energy. To facilitate comparisons, framework elements are categorized as: (1) research and innovation policies that help to develop emerging and improved technologies; (2) market-based policies that underwrite the cost of introducing technologies, provide a competitive framework, and may internalize externalities; and (3) regulatory advances that simplify and improve the efficiency of permitting offshore energy facilities.

\section{INTRODUCTION}

Offshore renewable energy development is a hot topic. Researchers involved in it are quite busy as the Obama administration pushes for regulation of carbon emissions, as oil prices steadily rise, and as technological advances quickly alter aspects of the policy context (e.g., relevant jurisdictions change because development can occur in deeper water). The topic has numerous facets, be they technological, environmental, or regulatory. The offshore renewable energy sector is developing at a highly uneven pace throughout the industrialized world and even among different regions within the United States (Kuffner, 2009); this variable pace generates significant interest in what policies, government mechanisms, and regulatory approaches will support wise development. In addition to developing a "menu" of regulatory options that encourage development, policymakers are interested in strategies that will help avoid detrimental aspects of development, such as unanticipated conflicts with competing uses for ocean space and environmental degradation.

Therefore, it is helpful to examine policies in different countries, particularly those with advanced experience in offshore renewable energy development, to characterize their regulatory practices and to look at what might be suitable for adoption or adaptation in the United States. What lessons are to be learned? How can policymakers emulate successful policies, and how can they avoid bad ones? This article concentrates on the policy-related aspects of siting and permitting of offshore renewable energy in various country contexts, particularly in Europe, with a strong focus on the UK and Germany, two countries moving quickly to expand energy development in the marine 
environment. Another interesting and relevant case is Portugal, which has just recently adopted a strong stance on cutting carbon emissions that envisions offshore renewable energy, particularly wave energy, taking on a significant role.

This article first describes the regulatory framework in the United States for siting and permitting of offshore renewable energy facilities, and then highlights policy features of programs in other countries. Initially, the article presents a brief historical background of regulatory development in the United States and summarizes its more salient features. Comparative descriptions of regulatory programs and policies in the UK, Germany, and Portugal follow. Given the breadth and complexity of what falls under the general theme of "policy," the text focuses on federal policies as set apart from state and local-level policies that support the sector, and on siting and permitting as these are limited to the processes of allocating ocean space, authorizing projects, and environmental impact assessment. I refer mainly to offshore renewable energy technologies considered relevant by the Alternative Energy and Alternative Use Program of the US Minerals Management Service. These technologies consist of offshore wind energy and hydrokinetic sources of energy generated in or over submerged lands.

\section{A BRIEF HISTORY OF THE} US REGULATORY SYSTEM Prior to 2005, there was no clear authority designated to approve offshore renewable energy facilities. Among many other entities, the National Oceanic and
Atmospheric Administration (NOAA), under the Department of Commerce, and the US Army Corps of Engineers had varying roles in the approval process. As developers started to show interest in ocean space for the exploitation of various types of energy beyond offshore oil and gas (for which the approval process is well established), there was confusion about how review of applications should proceed to limit redundancy and make the process effective (Martin and eliminated the OTEC office.

In 2005, Congress amended the Outer Continental Shelf Lands Act (43 U.S.C. $\$ \$ 1331$ et seq.) through the Energy Policy Act of 2005, giving the Department of the Interior (DOI), and subsequently DOI's Minerals Management Service (MMS), authority to issue leases, easements, or rights of way on the Outer Continental Shelf (OCS) for the production, transportation, or transmission of energy from

\section{S 6 ...IT IS HELPFUL TO EXAMINE POLICIES IN DIFFERENT COUNTRIES, PARTICULARLY THOSE WITH ADVANCED EXPERIENCE IN OFFSHORE RENEWABLE ENERGY DEVELOPMENT, TO CHARACTERIZE THEIR REGULATORY PRACTICES AND TO LOOK AT WHAT MIGHT BE SUITABLE FOR ADOPTION OR ADAPTATION IN THE UNITED STATES.}

and Smith, 2004). For example, in 1980, discrete authority was given to NOAA for licensing the construction, ownership, location, and commercial operation of ocean thermal energy conversion (OTEC) plants designed to exploit the temperature differential between different layers of seawater. This authority was granted under the Ocean Thermal Energy Conversion Act (42 U.S.C. $\$ \$$ 9101 et seq.). However, in 1996, in part because no OTEC license applications had been received and in part to meet the directive that all agencies eliminate or modify obsolete regulations, NOAA repealed the OTEC licensing regulations sources other than oil and gas. MMS then embarked on development of the Alternative Energy and Alternative Use (AEAU) program and the rule for implementation of the program. The rule ensures the orderly, safe, and environmentally responsible development of alternative energy sources and establishes the methods for sharing revenues generated on the OCS with

Michelle E. Portman (mportman@cc.huji. ac.il) is Golda Meir Fellow, Environmental Policy and Management Program, Department of Geography, The Hebrew University of Jerusalem, Jerusalem, Israel. 
nearby coastal states. After many months of holding public meetings on an environmental impact statement (EIS) that assessed the AEAU program (a programmatic EIS, or PEIS), and following a decision in 2007 on the PEIS, MMS published the final rule in the Federal Register on April 29, 2009 (74 FR 81, pp. 19,638-19,871). The rule, called the Renewable Energy and Alternative Uses of Existing Facilities on the OCS, has led to extensive guidelines to assist developers in complying with the rule. These guidelines were published in the beginning of August 2009 and thereafter MMS received the first bids for renewable energy projects in the OCS.

In general, the OCS begins $3 \mathrm{~nm}$, or approximately $5.5 \mathrm{~km}$, off coastal shorelines and extends to about $200 \mathrm{~nm}$ $(370 \mathrm{~km})$ seaward, with depths ranging from a few meters to thousands of technologies reviewed in the PEIS for the AEAU program give an indication of expected development projects off US shores (Minerals Management Service, 2007). These projects constitute capture technologies for offshore wind, wave, and ocean current (including tidal) energy. MMS anticipates receiving applications for development of these technologies on the OCS over the next five to seven years from the time of assessment (i.e., 2007-2014). Other technologies whose development is expected to be farther off include those for solar energy capture and for hydrogen energy storage and transport. Tidal energy projects are most suited to areas close to shore and therefore outside MMS jurisdiction. MMS was also given jurisdiction over other projects that make alternative use of existing oil and natural gas platforms in federal waters. Alternative

\section{$\checkmark$ WHAT LESSONS ARE TO BE LEARNED? HOW CAN POLICYMAKERS EMULATE SUCCESSFUL POLICIES, AND HOW CAN THEY AVOID BAD ONES?}

meters. Exceptions are offshore of Texas and Florida, where the OCS begins $9 \mathrm{~nm}(16.7 \mathrm{~km})$ offshore. However, for the relevant technologies, development is expected to occur relatively close to shore, where maximum water depth would be $100 \mathrm{~m}$ or less for wind and wave technologies and $500 \mathrm{~m}$ for ocean current technology.

Although the types of alternative energy projects that can be considered by the program are unlimited, the uses of existing facilities may include, but would not be limited to, renewable energy production, aquaculture, and research and monitoring. At this time, oil and gas structures are present only in OCS waters of the Gulf of Mexico and southern California (there are none in the Atlantic).

According to the rule and existing supporting regulation, a project must comply with various other applicable laws, such as environmental review under the National Environmental Policy Act (NEPA). Consultations or permits may also be required under the Endangered Species Act, the Magnuson-Stevens Act, the Marine Mammal Protection Act, the National Marine Sanctuaries Act, the Fish and Wildlife Coordination Act, and the Migratory Bird Treaty. US Coast Guard and Federal Aviation Administration regulations may apply regarding navigation and airspace issues. States may also have review authority under the federal consistency provision of the Coastal Zone Management Act (CZMA). An activity is subject to the consistency provision if it will "directly, indirectly, or cumulatively affect any natural resources, land uses, or water uses in the coastal zone." Section 307 of the CZMA requires that federal actions be consistent with enforceable policies of a state's federally approved coastal zone management program if they are reasonably likely to affect any land or water use or natural resource of the state's coastal zone.

\section{HIGHLIGHTS OF THE US REGULATORY SYSTEM}

The MMS final regulations and the accompanying (partial) guidance issued in April 2009 and August 2009, respectively, consist of a two-tiered system allowing developers to apply for a limited or a commercial lease. The former is restricted to a period of five years and would likely be for technological evaluations and site exploration. A commercial lease is for 25-30 years and includes a six-month planning period, a five-year assessment period, and a 25-year construction period. MMS requires both a rental fee and royalty payments from commercial leaseholders. 
The lease process begins with issuance of a call for nominations, followed by evaluation of the nominations, determination of the area to be leased, and finally issuance of a sale notice. MMS continues the process with an auction if there is competitive interest. If not, MMS will issue a noncompetitive lease through negotiation.

All lessees are responsible for initial environmental assessments (in accordance with NEPA) and later assessment following submission of construction and operation plans. Submission of the mandatory decommissioning plan also triggers NEPA review. These plans may or may not initiate a full-blown EIS, according to NEPA regulations. Developers will self-report on their compliance with safety and environmental monitoring plans while MMS will conduct both scheduled and unscheduled facility inspections. For decommissioning, an operator must furnish a surety bond, provide a decommissioning plan two years before the end of the lease, and complete decommissioning within two years of lease termination (Snyder and Kaiser, 2009).

The most salient features of the US regulatory system, when compared to the regulatory systems of Western European countries, are lack of development standards or proactive siting in the Exclusive Economic Zone (EEZ), such as through marine spatial planning or a strategic environmental assessment $(\mathrm{SEA})^{1}$ process. In contrast with a number of European countries, in the US there has been only recent clarification of the overall regulatory framework-especially with the purpose of reducing redundancy among agencies with overlapping jurisdiction. Also, the lease fees (rents and royalties) charged to developers for use of the seabed for renewable energy production distinguishes the US system from many of its European counterparts. Recommendations exist from the PEIS mentioned above that could serve as the basis for standards for offshore renewable development, although they require further adaptation.

Both MMS and the Federal Energy Regulatory Commission (FERC) are involved in regulation of energy projects; they have jurisdiction to issue leases and licenses (respectively) for hydrokinetic projects on the OCS (see Frank, 2010; Konnert, 2010). Agreement and consolidation of authority between the two agencies occurred only recently, in April 2009, with the signing of a memorandum of understanding (MOU). This MOU was a major accomplishment, because it allowed the joint issuance of MMS guidelines (mentioned above) in July $2009^{2}$.

Among other recent boosts to the marine renewable sector not tied to regulation is the availability of research funds from the federal government. This fiscal year (2010), the Department of Energy will award a total of about $\$ 40 \mathrm{M}$ for hydrokinetic energy research (Noblett, 2009).

\section{OFFSHORE RENEWABLE ENERGY IN OTHER COUNTRIES \\ Perhaps a more significant driver than the need for new sources of renew- able energy to reduce $\mathrm{CO}_{2}$ emissions is}

entrepreneurship and business interest in the development of applicable technologies. A 2006 report prepared for the International Energy Agency (IEA) on ocean energy systems identified 81 individual ocean energy concepts being developed in IEA member countries, including 53 ocean wave technologies, 25 tidal current devices, one OTEC system, and two salinity gradient concepts. Advances in research and development have motivated a number of governments, notably those with large ocean energy resources, to introduce policies dedicated to supporting the demonstration and deployment of ocean energy systems (AEA Energy \& Environment, 2006).

A review of significant policy advances of three European countries follows; it characterizes the approaches, highlights key developments, and summarizes policy obstacles to offshore renewable energy overall. For purposes of comparison, policy-related features of development are categorized as: (1) research and innovation policies that help to develop emerging and improved technologies (e.g., government research, development, and demonstration programs); (2) market-based policies that underwrite the cost of introducing technologies into the market, provide a competitive market framework, and may internalize externalities in terms of energy security, environmental protection, and economic efficiency; and (3) regulatory advances that simplify and improve the efficiency of permitting offshore energy facilities (see Table 1).

\footnotetext{
${ }^{1}$ Although some policy analysts equate PEIS with SEA, according to the SEA Directive of the European Union (2001/42/EC), SEA applies only to plans and programs, not policies.

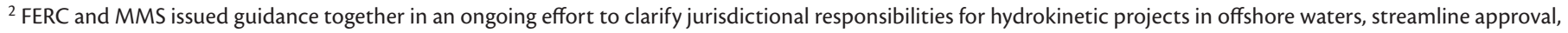
and encourage development. This guidance provides information to applicants and stakeholders about the respective responsibilities of each agency and how to best navigate the process of obtaining leases and licenses for projects on the OCS.
} 
Table 1. Country comparisons: salient examples in each policy category

\begin{tabular}{|l|l|l|l|}
\hline Country & Research \& Innovation & Market-based incentives/controls & Regulatory improvements \\
\hline UK & Earmarking of lease fee & Sales of renewable obligation credits & Establishment of Marine Management Organization \\
\hline Germany & $\begin{array}{l}\text { Government-supported } \\
\text { offshore wind R\&D }\end{array}$ & $\begin{array}{l}\text { “Bonus" feed-in tariffs for } \\
\text { offshore wind }\end{array}$ & $\begin{array}{l}\text { Renewable energy plant approval: } \\
\text { Nondiscretionary administrative act }\end{array}$ \\
\hline Portugal & $\begin{array}{l}\text { Government support for } \\
\text { Wave Energy Center }\end{array}$ & Feed-in tariff for wave energy & $\begin{array}{l}\text { Streamlined approval for projects in Maritime } \\
\text { Pilot Zone }\end{array}$ \\
\hline US & $\begin{array}{l}\text { DOE funding for marine } \\
\text { renewable energy research* }\end{array}$ & $\begin{array}{l}\text { Production tax credits for } \\
\text { renewable energy }\end{array}$ & MMS/FERC cooperation \\
\hline
\end{tabular}

*An example: The US Department of Energy recently made a grant of $\$ 1 \mathrm{M}$ to the New England Marine Renewable Energy Center (Dartmouth, Massachusetts) for research on technologies using offshore tides, wind, and waves.

UK: Proactive Siting and a "One-Stop Shopping" Approach

The UK has one of the largest practical resources in Europe: just for offshore wave power and tidal power, it is estimated that the country has around $50 \mathrm{TWh} /$ year (1 terawatt-hour or $1 \mathrm{TWh}=1$ billion kilowatt-hours) and $18 \mathrm{TWh} /$ year, respectively, equivalent to around $18 \%$ of the country's annual electricity consumption (Ferro, 2006). The UK's Crown Estate, which holds property rights for submerged areas in public trust, ${ }^{3}$ has solicited bids for leasing of offshore areas for renewable energy development during three rounds. The first two rounds, held in April 2001 and December 2003, resulted in a total of 35 agreements between the Crown and energy developers. The Crown Estate launched Round 3 of offshore wind leasing in June 2008 and concluded issuing bids and awards at the end of 2009 (The Crown Estate, 2009).

A policy that aims to improve the state of research and innovation is the earmarking of a one-time fee paid by successful lease applicants for support of research and education projects committed to furthering the offshore wind industry (Snyder and Kaiser, 2009). The greatest focus is on wind initiatives, but the wave and tidal sector also get attention in the UK. In 2006, the British government launched the Wave and Tidal Stream Energy Demonstration Scheme, which provides capital grants and revenue support for pre-commercial demonstration of ocean energy system farms. Although developers pay a onetime lease fee for the use of UK ocean space, financial incentives are available to them in the form of capital grants, exemption from the climate change levy (4.3 pence per $\mathrm{kWh}[\mathrm{p} / \mathrm{kWh}]$ ), and through the opportunity to sell renewable obligation credits ( $5 \mathrm{p} / \mathrm{kWh}$ ).

In addition to public funding and some market-based incentives, ocean energy development is facilitated by proactive identification of potential sites and a clear regulatory framework. For the second round of leasing held for wind development off the UK coast, developers were required to submit proposals that fell within one of three strategic areas designated by the government for wind projects, areas for which preliminary environmental assessments had been completed. As for streamlining approval, there is recognition in the UK that policies need reform. Although the UK declared a Renewable Energy Zone (REZ) under the provisions of Chapter 2 of the Energy Act 2004, the approval process for offshore renewable energy projects was still regulated under several pieces of legislation, each with their own separate approval and consent processes. The UK's Marine and Coastal Access Act, passed in early November 2009, has created a new Marine Management Organization (MMO) that will now be the main planning body charged with managing activities in the coastal areas of the UK, including the REZ. The Act also establishes a new marine planning system that will set long-term objectives for use and management of those UK waters to which it applies (as well as a series of more detailed marine plans and

\footnotetext{
${ }^{3}$ The marine portion of the UK Crown Estate comprises over 55\% of the UK's foreshore, the beds of tidal rivers and estuaries, and almost all of the seabed out to the 12-nm territorial limit around the UK. It also includes the rights to explore and utilize the natural resources of the UK continental shelf with the exception of oil, gas, and coal.
} 
spatial policy for particular regions). The Act requires proponents of offshore renewable energy projects to obtain a single consent to construct and operate a renewable energy project from the MMO (Leary and Esteban, 2009).

\section{Germany: Cautious But Committed}

Germany has limited ocean energy resources in comparison with other European countries (AEA Energy \& Environment, 2006). Shallow coastal areas and protections in the Wadden Sea National Park along Germany's North Sea coast have excluded any energy development along the shoreline in coastal-state territorial waters. But ocean energy is included under the existing renewable framework, and this framework supports offshore wind development. An example of a relatively deep-water initiative is the Alpha Ventus experimental wind park that started operating in August 2009, 45 km off the German coast. The farthest existing European wind parks operated only up to $20 \mathrm{~km}$ offshore until the construction of Alpha Ventus.

Despite its falling behind both the UK and Denmark in offshore renewable energy currently generated, Germany has made important strides in governmentsupported R\&D, in market-based incentives, and in streamlining the regulatory process. Led by the Federal Environment Ministry, the government launched a public-private partnership program in July 2005-the Offshore Wind Energy Foundation-comprised of members of the offshore wind power industry, power utilities, financiers, nongovernmental organizations, representatives of coastal states, and other federal ministries. The short-term goal of the foundation was to develop the first offshore wind farm in the North Sea. To this end, the foundation started constructing a test bed near the island of Borkum with twelve 5-MW turbines (Portman et al., 2009). In 2007 alone, the German government dedicated $€ 34.6 \mathrm{M}$ for new research and development of wind energy, two-thirds for offshore wind energy (BMU, 2008).

Germany's market-based incentives include feed-in tariffs that have been successful at encouraging onshore renewable energy development. Since January 2009, they include significant "bonus" amounts for offshore wind, an acknowledgment of the higher costs of moving into the offshore environment. Projects producing offshore wind energy by 2016 will get a $€ 0.02 / \mathrm{kWh}$ starting bonus for a total guaranteed rate of $€ 0.15 / \mathrm{kWh}$.

As for the regulatory process, Germany's authorizing agency, the Federal Maritime and Hydrographic Agency (BSH) has led the process for developing standards for wind farm authorizations, operations, and decommissioning since 2001, and these standards are being revised in an ongoing fashion. The agency has developed standards based on onshore wind experience, the experiences of other countries, and German government-supported $\mathrm{R} \& \mathrm{D}$ efforts focused on the offshore sector. German law expedites the approval of offshore renewable energy projects by considering authorization a nondiscretionary administrative act (gebundene Entscheidung; Portman et al., 2009). As such, the presumption is in favor of approval that is rebuttable only by specific reasons of a limited nature (e.g., impairment of safety and/or efficiency of navigation or threat to the marine environment). Even so, as of mid 2009, BSH has approved close to 19 wind farms in the German EEZ, but only test farms have been constructed.

Portugal's Pilot Zone:

The Fast Lane

Portugal has one of the largest EEZs of the European continent, especially in relation to the country's land area. Portugal's good wave energy resources and its heavy dependency on foreign sources of power have encouraged the dedication of Portuguese scientists to ocean energy exploitation for more than three decades. The main ocean energy technologies developed in Portugal include oscillating wave column technology (OWC), wave attenuators, and wave farms. The Portuguese government faces tight emission commitments for the Kyoto Protocol (a reduction of $8 \%$ from 1990 levels by 2012), and at the same time projections of strong energy demand growth (14\% increase predicted between 2002 and 2010). These constraints resulted in wave energy being included in the National Ocean Strategy and the National Energy Strategy in 2005 and 2006, respectively. A large portion of the 2010 target for renewable energy generation set by the National Energy Strategy established in 2001 refers to wave energy specifically (AEA Energy and Environment, 2006).

Important developments in the ocean energy sector began occurring earlier in the decade, for example in 2003, when a group of 10 mainly Portuguese companies, universities, and $R \& D$ institutes formed the Wave Energy Center. Government support for Portuguese scientists working on wave energy applications has been significant 
with $€ 5 \mathrm{M}$ committed for ocean energy research, development, and demonstration projects per year from 2000 to 2009 (AEA Energy \& Environment, 2006). Since 2003, the Portuguese Innovation Agency's DemTec program, which funds pilot projects related to technologically innovative products, processes, and systems, supported the renovation and testing of the Pico OWC Pilot Plant international) regulations (Palha et al., 2010). Other than its R\&D goals, the Maritime Pilot Zone is meant to guarantee simplified and fast licensing and permitting through a managing body that will also identify and promote the establishment of offshore corridors and the construction and maintenance of surrounding (including land-based) sector infrastructure (Waveplam, 2008).

BASED ON THE EXPERIENCES OF OTHER COUNTRIES, PARTICULARLY IN EUROPE, WITH THE RIGHT POLICIES IN PLACE, US INTERESTS IN THE OFFSHORE RENEWABLE ENERGY SECTOR CAN BE SERVED BY GREATER TECHNOLOGICAL ADVANCES, CONTINUED COST REDUCTION, AND STREAMLINED PERMITTING.

in the Azores, the AWS Company's wave energy converter full-scale demonstration, the Douro Breakwater OWC, and the Pelamis demonstration wave farm project (AEA Energy \& Environment, 2006).

In January 2008, the Portuguese government created a Maritime Pilot Zone off the Portuguese coast for wave energy extraction to support the deployment of offshore wave energy prototypes and farms. This maritime pilot zone is located off the west coast of São Pedro de Moel, between $30 \mathrm{~m}$ and $90 \mathrm{~m}$ water depth, with an area of $320 \mathrm{~km}^{2}$. The main $R \& D$ objective is to monitor and learn from field results. Knowledge gleaned from this test site will be used for the development of Portuguese (and
Since 1999, Portugal's feed-in tariffs for renewable sources of energy are determined by the technology used for generation, according to a formula that is based on an environmental package associated with avoiding $\mathrm{CO}_{2}$ emissions. The formula is also designed to encourage projects of a smaller scale for areas with fewer natural resources to exploit. In 2004, the government guaranteed wave energy one of the highest feed-in tariffs (between $€ 145 / \mathrm{MWh}$ and $€ 280 / \mathrm{MWh}$ ) - higher only for electricity generated from solar sources (Renewable Energy Action, 2004). It is yet unclear how successful the feed-in tariffs will be at encouraging offshore wind or wave energy. Thus far, feed-in tariffs for renewable sources have been mostly applied for onshore wind. A test case was established in 2008 when the Portuguese government agreed to a feed-in tariff with a wave energy developer of $€ 0.23 / \mathrm{kWh}$ for generation within the ocean energy pilot zone.

\section{LESSONS FOR POLICY DEVELOPMENT}

From the growing literature on the subject and the summary presented here, it is apparent that the best supporting policies for development of offshore renewable energy are dependent on the context within which they are formulated, adopted, and implemented. Context broadly encompasses a country's regulatory regime, onshore and offshore physical conditions, available ocean resources, and political and social constructs. However, some overall conclusions can be drawn from the experiences of other countries, and policies should be aimed at solving a number of problems inherent to the offshore renewable energy sector.

Overall, poor data on the resource potential of ocean energy has hindered widespread support for policies that could jumpstart marine renewable energy initiatives. More research funding needs to go into understanding the scale of ocean energy as a resource and disseminating this information. Regarding technological impediments and development of the nascent offshore sector, policies should aid the demonstration of full-scale prototypes because lack of such demonstration projects is an identified barrier to development (AEA Energy \& Environment, 2006). Programs and policies should be available particularly to offset the exorbitant cost of connecting demonstration projects to 
the electricity grid.

In the regulatory sphere, countries should cooperate to craft internationally recognized standards for developing, testing, and measuring marine renewable energy technologies. They could also benefit from the exchange of experience with regard to environmental impact assessments for commercialscale ocean energy projects. Regulatory frameworks are uncertain for this sector, which partially stems from limited experience in applying existing regulatory regimes beyond the territorial sea (Leary and Esteban, 2009). These are all areas where countries can both learn from one another and learn from other sectors, such as offshore mining and commercial fishing.

It is natural that in the rush for renewable energy, developers in countries and regions with plentiful land resources available for large energy projects, such as those needed for solar energy panel fields or expansive wind farms, may be reluctant to move into the ocean environment, regardless of public policy. However, in countries with certain geographical conditions, such as plentiful offshore wind and wave resources available close to load centers where plentiful electrical energy is needed by consumers, and a lack of other options (such as in northeastern United States and the Pacific Northwest), marine renewable energy is likely the next energy frontier. It is the government's role to support and encourage renewable energy generation where good resources and significant needs coincide. This should be accomplished while seeking compensation for the use of public resources, protecting the environment, and avoiding conflicts in uses of ocean (and coastal) space.
Learning from a variety of international experiences can contribute a lot. Based on the experiences of other countries, particularly in Europe, with the right policies in place, US interests in the offshore renewable energy sector can be served by greater technological advances, continued cost reduction, and streamlined permitting. 伲

\section{REFERENCES}

AEA Energy \& Environment. 2006. Review and Analysis of Ocean Energy Systems Development and Supporting Policies: A Report By Area Energy \& Environment on Behalf of Sustainable Energy Ireland for the IEA's Implementing Agreement on Ocean Energy Systems. Implementing Agreement on Ocean Energy Systems, 59 pp. Available online at: http://www. iea-oceans.org/_fich/6/Review_Policies_on_ OES_2.pdf (accessed March 9, 2010).

Böhme, D., W. Dürrschmidt, M. van Mark, F. Staiß, C. Linkohr, F. Musiol, M. Ottmüller, eds. 2008. Development of Renewable Energies in Germany in 2007. Federal Ministry for the Environment, Nature Conservation and Nuclear Safety (BMU), Division KI III 1 (General and Fundamental Issues Relating to Renewable Energies), Berlin, 9 pp. Available online at: http://download. inogate.org/Seminar\%2015-16\%20April\%20 2008\%20\%93EE,\%20DSM\%20\&\%20RES\%94/ DENA\%20Documentation/background_paper_ renewables_Germany_2007_en.pdf (accessed March 23, 2010).

Ferro, B.D. 2006. Wave and tidal energy: Its emergence and the challenges it faces. Refocus 7(3):46-48.

Frank, W.J. 2010. The role of the Minerals Management Service in offshore renewable energy development. Oceanography 23(2):60-67.

Konnert, T. 2010. The role of the Federal Energy Regulatory Commission in authorizing hydrokinetic technology projects. Oceanography 23(2):54-59.

Kuffner, A. 2009. Several companies want to be the first to develop an offshore wind farm in the U.S. The Providence Journal, August 16, 2009. Available online at: http://www.projo.com/ news/content/OFFSHORE_WIND_RACE_0816-09_EBF0D97_v107.3eaefee.html (accessed March 8, 2010).

Leary, D., and M. Esteban. 2009. Climate change and renewable energy from the ocean and tides: Calming the sea of regulatory uncertainty. The International Journal of Marine and Coastal Law 24:617-651.
Martin, G.R., and O.A. Smith. 2004. The world's largest wind energy facility in Nantucket Sound? Deficiencies in the current regulatory process for offshore wind energy development. Boston College Environmental Affairs Law Review 31(2):285-323.

Minerals Management Service. 2007. Final Alternative Energy Programmatic EIS (ES-1): Executive Summary. Department of Interior, Washington, DC. 16 pp. Available online at: http://ocsenergy.anl.gov/documents/fpeis/ Alt_Energy_FPEIS_ExecutiveSummary.pdf (accessed March 9, 2010).

Noblett, J. 2009. Marine energy research center gets $\$ 1 \mathrm{M}$ in funding. Boston Business Journal, June 19, 2009. Available online at: http://boston. bizjournals.com/boston/stories/2009/06/22/ story17.html (accessed March 9, 2010).

Palha, A., L. Mendes, C.J. Fortes, A. Brito-Melo, and A. Sarmento. 2010. The impact of wave energy farms in the shoreline wave climate: Portuguese pilot zone case study using Pelamis energy wave devices. Renewable Energy 35(1):62-77.

Portman, M.E., J.A. Duff, J. Köppel, J. Reisert, and M.E. Higgins. 2009. Offshore wind energy development in the exclusive economic zone: Legal and policy supports and impediments in Germany and the US. Energy Policy 37(9):3,596-3,607.

Renewable Energy Action. 2004. Feed-in Tariffs for Wind Energy-Case Study \#25 (Portugal). Renewable Energy Action, 8 pp. Available online at: http://www.senternovem.nl/mmfiles/ Feed-in\%20tariffs\%20for\%20wind\%20energy_ tcm24-116990.pdf (accessed October 28, 2009).

Snyder, B., and J.M. Kaiser. 2009. Offshore wind power in the US: Regulatory issues and models for regulation. Energy Policy 37(11):4,442-4,453.

The Crown Estate. 2009. Round 3: Developers. Available online at: http://www. thecrownestate.co.uk/r3-developers (accessed January 31, 2010).

Waveplam. 2008. Portugal: A rising marketplace for wave energy? Available online at: http://www. waveplam.eu/page/default.asp?id=175 (accessed March 9, 2010). 